\title{
Making the Case for Genocide, the Forced Sterilization of Indigenous Peoples of Peru
}

Ñusta P. Carranza Ko

University of Baltimore

Follow this and additional works at: https://digitalcommons.usf.edu/gsp

\section{Recommended Citation}

Carranza Ko, Ñusta P. (2020) "Making the Case for Genocide, the Forced Sterilization of Indigenous Peoples of Peru," Genocide Studies and Prevention: An International Journal: Vol. 14: Iss. 2: 90-103. DOI:

https://doi.org/10.5038/1911-9933.14.2.1740

Available at: https://digitalcommons.usf.edu/gsp/vol14/iss2/8

This Articles is brought to you for free and open access by the Open Access Journals at Digital Commons @ University of South Florida. It has been accepted for inclusion in Genocide Studies and Prevention: An International Journal by an authorized editor of Digital Commons @ University of South Florida. For more information, please contact digitalcommons@usf.edu. 


\title{
Making the Case for Genocide, the Forced Sterilization of Indigenous Peoples of Peru
}

\author{
Ñusta P. Carranza Ko \\ University of Baltimore \\ Baltimore, Maryland, USA
}

Genocide is a word that commissioners involved with Peru's Truth and Reconciliation Commission (2001-2003) avoided when defining what had taken place during the two decades (1980-2000) of Peru's internal armed conflict. The political violence between the state, leftist guerilla forces (i.e., the Shining Path and the Revolutionary Movement of Tupac Amaru), and the civilians that were caught in the middle, resulted in the disappearances and deaths of over 69,000 victims. According to the commissioners, the mass casualties were not a result of a genocide. ${ }^{1}$ There was no plan either from the Peruvian state-the three administrations of Belaúnde Terry (1980-1985), Alan García (1985-1990), and Alberto Fujimori (1990-2000) - or the guerilla forces to systematically destroy groups of people, making it difficult to bring up the term in connection with the conflict. That is, even though the majority of the victims shared strangely similar characteristics of residing in poor rural areas and speaking indigenous languages as their mother tongue.

And yet, a genocide did occur. The destruction of the collective rights of a group of people, however, was not directly tied to the political dynamics of the internal armed conflict, in that it did not involve interactions between the state, leftist subversive groups, and civilians. Nor did it resemble the characteristics of other commonly occurring crimes from this period, such as torture, arbitrary detention or disappearances. For this reason, genocide was not referenced in the seventy-three individual cases of violations that were investigated and published by the Truth and Reconciliation Commission's Final Report in 2003. ${ }^{2}$ However, there was a case of genocide that involved the state against the reproductive rights of an ethnic minority, an institutionalized genocide via a state policy.

Over the course of five years from 1996 to 2001, under the disguise of the Programa de Salud Reproductiva y Planificación Familiar (Program of Reproductive Health and Family Planning (PSRPF)), the state intentionally launched a genocidal policy that aimed to destroy, in whole or in part, a specific population within Peru. The population consisted of women (and some men) of poor, rural, and Indigenous-languages-speaking backgrounds who were sterilized without consent, misinformed of the practice, and forced to undergo surgery. ${ }^{3}$ In referring to the bad practices of forced sterilization that emerged from this health program, the executive secretary of the National Coordination of Human Rights, Ana María Vidal described it as "the trashing of human rights, in this case of Indigenous women." ${ }^{4}$ The comment reflected the stigmatized situation of the Indigenous population in Peru, as a marginalized group whose status had been fixed in this position since the adoption of the first Constitution of Peru in 1823. Under Article 17, the Constitution conditioned citizenship based on property ownership and literacy in Spanish, ${ }^{5}$ both hard to reach by Indigenous populations with different linguistic traditions and notions of territory. A century and a half later, the state targeted the Indigenous population with a policy of reproductive health and coercive sterilization that undermined Indigenous women's ability to reproduce and in doing so, destroy the future generations of Indigenous peoples. And yet, while the signs were there to link this human rights violation to genocide, the case went unnoticed by human

${ }^{1}$ Francisco Soberón (former Truth and Reconciliation Commission commissioner and founder of Asociación Pro-Derechos Humanos (APRODEH)), interview by author, Baltimore, May 19, 2019.

${ }^{2}$ Comisión de la Verdad y Reconciliación, Final Report (Lima: Comisión de la Verdad y Reconciliación, 2003), accessed August 1, 2019, http://www.cverdad.org.pe/ingles/ifinal/index.php.

${ }^{3}$ Defensoría del Pueblo, Decimonoveno Informe Anual de la Defensoría del Pueblo (Lima: Defensoría del Pueblo, 2015), 50-53.

${ }^{4}$ Ana María Vidal (Executive Secretary of the National Coordination of Human Rights), interview by author, Lima, June 1, 2017.

${ }^{5}$ Constitución Política de la República Peruana Sancionada por el Primer Congreso Constituyente (Political Constitution of the Republic of Peru Approved by the First Constituent Congress) (November 12, 1823), (Republic of Peru), accessed August 1, 2019, http://www.leyes.congreso.gob.pe/Documentos/constituciones ordenado/CONSTIT 1823/

Cons1823 TEXTO. pdf. 
rights and genocide studies scholars. Existing studies on Peru characterize forced sterilization as an example of sexual violence, a violation of Indigenous peoples' rights $^{6}$ or at most, a form of crime against humanity. ${ }^{7}$ Even an expansive usage of the term genocide, such as those used by scholars to explain how all the processes and patterns in the history of "North-American settler-Indigenous relations" were genocidal, ${ }^{8}$ is missing in the coercive sterilization literature on Peru. In fact, it was not until an audience member (at a talk given by the author) posed a question of whether the Peruvian case could be considered a form of genocide that the author began thinking about the connection between forced sterilization and the human rights norm. That interaction sparked this study on making the case for genocide.

This study considers the forced sterilization of Indigenous women in Peru as a genocide. Using the normative definitions from the 1948 Convention on the Prevention and Punishment of the Crime of Genocide (or the Genocide Convention), it first categorically sets forced sterilization victims from this state-led-policy as victims of genocide, considering the effects the health malpractice had on Indigenous women's reproductive rights and future Indigenous populations. Then, it grounds the discussion of genocide further by arguing for the genocidal intent of the Peruvian state, relying on victims' testimonies, interviews from human rights experts, archival data from victims' registries, government documents, and human rights ombudsman office reports. These discussions contribute to the existing body of scholarship on the link between genocide and forced sterilization of Indigenous women - namely in the United States and Canada. ${ }^{9}$ Making the case for genocide, one of the most heinous crimes in international politics, has not been done previously with this particular case. Even in María Mamérita Mestanza Chávez v. Peru, where a petition was lodged by domestic and international nongovernmental organizations with the Inter-American Commission on Human Rights (IACHR) against the Peruvian state for María's forced sterilization, subsequent health complications, and death on April 5, 1988; there were no references to genocide. ${ }^{10}$

It is important to acknowledge this crime as a genocide because, first and foremost, this case was the most modern attempt from the governing apparatus of Peru-largely reflecting colonial hierarchies of power with those of European or of mixed European descent in political controlat targeting Indigenous peoples from rural and impoverished regions. Previous genocides involving the groups in power were considerably different in nature. During the historic period of the colonization of the Americas, one might argue that the Spanish empire and its soldiers unknowingly brought upon the genocide of the Indigenous peoples via the spread of diseases from Eurasia (e.g., chicken pox) which led to the death of Indigenous peoples not immunologically prepared to resist new viruses. Nor was coercive sterilization a type of genocide that resulted from the internal armed conflict, when the leftist guerilla group Sendero Luminoso (Shining Path) killed and disappeared over 5,000 Ashaninka-speaking and Nomatsiguenga-speaking Indigenous peoples from Peru's Amazon region. ${ }^{11}$ The evidence that this article lays out confirms that the

\footnotetext{
${ }^{6}$ Nusta Carranza Ko, "Forcibly Sterilized: Peru's Indigenous Women and the Battle for Rights," in Human Rights as Battlefields: Changing Practices and Contestations, ed. Gabriel Blouin-Genest et al. (New York: Palgrave Macmillan, 2019), 149-172.

${ }^{7}$ José Burneo Labrín, Justicia de Genero: Esterilización Forzada En El Perú: Delito de Lesa Humanidad (Lima: Editorial Linea Andina, 2008), 14-22.

${ }^{8}$ Cynthia C. Wesley-Esquimaux and Magdalena Smolewski, Historic Trauma and Aboriginal Healing (Ottawa: Aboriginal Healing Foundation, 2004), 7.

${ }^{9}$ Studies on aboriginal women in Canada have determined that they were disproportionately targeted by the state to undergo tubal ligations. The coercive sterilization of Indigenous peoples is best understood within the larger relations of "colonialism, the oppression of women," and the control of Indigenous peoples' land and resources, and it is one that constitutes a genocide. Similar studies in the United States have documented how colonizers have historically used sexual violence, such as sterilization abuse, as a primary tool of genocide against Indigenous peoples; see Karen Stote, "The Coercive Sterilization of Aboriginal Women in Canada," American Indian Culture and Research Journal 36, no. 3 (2012), 117; Andrea Smith, Conquest-Sexual Violence and American Indian Genocide (Durham: Duke University Press, 2005), 117.

${ }^{10}$ Inter-American Commission on Human Rights (IACHR), Report No. 71/03. Petition 12.191. Friendly Settlement María Mamérita Mestanza-Chávez, (Peru: IACHR, 2003), accessed August 1, 2019, http://cidh.org/annualrep/2003eng/ Peru.12191.htm.

${ }^{11}$ Julio Davila Puño, Perú: Gobiernos Locales y Pueblos Indígenas (Lima: Tarea Grafica Educativa, 2005), 35.
} 
family planning program was a genocidal policy with the objective of controlling the bodies and those of the children of Peru's Indigenous peoples. And, as such, it provides a telling case of where Indigenous peoples' rights stand in Peru today. Second, the weight of the word genocide can bring positive possibilities in dealing with the needs of the victims in receiving some form of justice and reparations related to their case. The state aimed to deliberately prevent future births from the group, and in doing so destroy at least a part of the Indigenous population. However, the search for criminal accountability with this case has faced obstacles of impunity, as evidenced in the 2016 decision by the Public Prosecutor's Office to shelve 2,074 cases of forced sterilization due to "insufficient information." ${ }^{12}$ The acknowledgement of this case as a genocide-a crime of crimes - can provide victims with even more impetus to put forth their case. Notably, referencing genocide for victims that face difficulties in their legal battles against the state, provides them with an additional tool to urge the state to recognize its responsibility in this heinous crime.

\section{Sexual Violence, Indigenous Peoples' Rights, and Human Rights}

Studies on coercive sterilization in Peru examine this atrocity under the framework of sexual violations - as a case of women's reproductive rights and Indigenous peoples' rights violations. Within these rights violations, some scholars focus on the societal dynamics of discrimination that played a part in the victimhood of the Indigenous population. Ballón documents the cartography of the resistance movement in Peru against forced sterilization. ${ }^{13}$ She describes how the resistance began when local women's and human rights groups started receiving information on abuses related to the family planning program. As the situation aggravated, domestic advocacy groups communicated their concerns to international human rights organizations. The message resonated and soon a network of international and domestic advocacy formed, along with the involvement of the artistic community in Peru-who helped maintain the subject of forced sterilization in the public discourse through their artistic representations of art, performance, and exhibitions. In discussing the works of resistance, Ballón explains how the resistance movement embodied a postcolonial criticism, as the family planning policy was built upon abuses of political power, discrimination, classism, racism, machismo (patriarchal notions of society), misogyny, and a depreciation of indigenous culture and identity. ${ }^{14}$ These were also similar ideas present in other modern family planning programs in countries such as Canada and the United States, where ideas of population control revolved around the history of colonialism, control of "aboriginal peoples' land and resources," and the "denial of indigenous sovereignty."15

Exploring the status of Peru's Indigenous peoples' marginalization further, del Aguila discusses how the Peruvian government's family planning campaign reflected deep-rooted racial discrimination and unequal treatment of this ethnic group. ${ }^{16}$ Racial inequality and the urban-rural divide from the Spanish colonial period set the Indigenous peoples apart from those of European heritage, with the European side identifying with the urban and superior race and the Indigenous associating with the rural, poor, and weaker race. Such visions were reflected in the Peruvian government's projection of the family planning policy towards a predominant indigenous population. Del Aguila explains how Fujimori's discourse was used to manipulate Indigenous peoples in the rural areas and documents malpractices of government health practitioners coming from urban areas, who did not speak Indigenous languages, and who were of mixed European heritage. They subjugated and forced Indigenous women with false information to accept

\footnotetext{
${ }^{12}$ La República, "Denuncia de Esterilizaciones Forzadas Fue Archivada por la Fiscalía," La República, July 27, 2016, accessed June 2, 2019, http://larepublica.pe/sociedad/789156-denuncia-de-esterilizaciones-forzadas-fue-archivada-porla-fiscalia.

${ }^{13}$ Alejandra Ballón Gutiérrez, "El Caso Peruano de Esterilización Forzada: Notas Para una Cartografía de Resistencia," Aletheia 5, no. 9 (2014), 15.

${ }^{14}$ Ibid., 15.

${ }^{15}$ Stote, The Coercive Sterilization, 117.

${ }^{16}$ Ernesto Vasquez del Aguila, “Invisible Women: Forced Sterilization, Reproductive Rights, and Structural Inequalities in Peru of Fujimori and Toledo," Estudos e Pesquisas em Psicología UERJ RJ 6, no. 1 (2006), 109-124.
} 
sterilization. ${ }^{17}$ Such societal interactions were made possible in the context of Peru's society where Indigenous peoples in rural areas were treated as inferiors in comparison to those coming from the urban centers with a lighter skin complexion.

Carranza $\mathrm{Ko}^{18}$ extends del Aguila's argument in connection with other structural factors to argue that the crime of forced sterilization represented the intersection of gender, ethnicity, and socioeconomic class dynamics in Peruvian society that dates back to the colonial period. On gender, Mantilla Falcón argues that it is important for the Peruvian state to acknowledge the case as a violation of women's reproductive rights and recognize the international documents that protect women's rights. ${ }^{19}$ These include: the right to reproductive health, right to life without discrimination and violence on the basis of gender, right to education, and the right to liberty and personal security. Using the lens of critical interculturality, De La Cruz Huamán focuses on some of the same intersections, particularly the hierarchy of order and domination (including gender) reproduced from the colonial period in different cultures that have generated multiple inequalities. ${ }^{20}$ The victim's identity - a majority of whom are women of Indigenous origin who lived in conditions of poverty, point to these inequalities and intersections, and the Peruvian state partook in the process of abuse as the new oppressor. Ewig emphasizes the economic and societal aspect further, explaining how Fujimori launched his campaign stemming from Thomas Malthus's idea of overpopulation, resource depletion, and economic downturn. ${ }^{21}$ Fujimori used the fight against poverty and the messaging of economic advancement as a justification for a family planning campaign which included forced sterilization. Boesten raises similar views, emphasizing how the neo-Malthusian-motivated policies were implemented to address the "Indian problem." 22 This was a well-known practice previously used by population control policies in countries such as South Africa. Kuumba explains how Malthusian-inspired birth control programs blamed African women for "their own poverty and underdevelopment as a result of their population growth," and targeted "blacks without a concomitant emphasis on the rest of the population." 23

Connecting the ideas of Indigenous peoples' exclusion in Peru and victimhood, Getgen ${ }^{24}$ critically evaluates the role of Peru's Truth and Reconciliation Commission (TRC) in not documenting the forced sterilization of Indigenous women and men. ${ }^{25}$ The TRC's voluntary omission of the state's forced sterilization of Indigenous women in the Final Report (2003), reveals the restrictions the Commission faced in presenting an overarching narrative of all the human rights crimes that occurred during the internal armed conflict. ${ }^{26}$ And, the exclusion of this group of victims in the

${ }^{17}$ Ibid., 115.

${ }^{18}$ Carranza Ko, Forcibly Sterilized.

${ }^{19}$ Julissa Mantilla Falcón, "El Caso de las Esterilizaciones Forzadas en el Perú Como una Violación de los Derechos Humanos," Ius et Veritas 23, (2016), 19.

${ }^{20}$ Rosario B. De La Cruz Huamán, "Análisis de las Esterilizaciones Forzadas en el Perú desde una Perspectiva de Interculturalidad Critica," Tierra Nuestra 12, no. 1 (2018), 109.

${ }^{21}$ Christina Ewig, "La Economía Política de Esterilización Forzada en el Perú," in Memorias del Caso Peruano de Esterilización Forzada, ed. Alejandra Ballón (Lima: Biblioteca Nacional del Perú, 2014), 17.

${ }^{22}$ Jelke Boesten, "Free Choice or Poverty Alleviation? Population Politics in Peru under Alberto Fujimori," European Review of Latin American and Caribbean Studies 82, (2007), 3.

${ }^{23}$ Monica Bahati Kuumba, "Perpetuating Neo-Colonialism through Population Control: South Africa and the United States," Africa Today 40, no. 3 (1993), 80.

${ }^{24}$ Jocelyn E. Getgen, “Untold Truths: The Exclusion of Enforced Sterilizations from the Peruvian Truth Commission's Final Report," Boston College Third World Law Journal 29, no. 1 (2009), 1-34.

${ }^{25}$ The mandate of the Truth and Reconciliation Commission covered all forms of violations of fundamental rights including acts perpetrated by state and armed groups from 1980 to 2000. From its work, the Commission determined that the causes of conflict were instigated by Sendero Luminoso, which had declared a popular war against the Peruvian state. The conflict and resulting human rights violations were one that involved the state, subversive forces (such as Sendero), and civilians who were caught in the middle. From this perspective, forced sterilization practices fell outside the markers of the internal armed conflict, as they did not involve a conflict between the state, subversive forces, and civilian casualties; see Carranza Ko, Forcibly Sterilized, 168.

${ }^{26}$ Getgen, Untold Truths, 4 . According to human rights experts, while forced sterilization occurred during the internal armed conflict, it fell outside the political systems that defined this period, with violent confrontation between leftist groups advancing their revolutionary goals and the state instituting a militarist response. Soberón, interview by author; 
TRC's Final Report made it significantly more difficult for victims, predominantly poor indigenous Quechua-speaking women, to seek accountability.

Other scholars have been more cautious to categorize the Indigenous peoples in Peru as those who were only victimized. Serra explains how victim-centric approaches to the discourse on forced sterilization evolved around a single objective of identifying the victims, revealing the suffering, and urging for justice. ${ }^{27}$ She argues that this scope of victim-based discourse contributes to stereotyping Indigenous populations as passive vulnerable actors and restricting sterilizations to be examined only through a human rights lens.

While existing research on forced sterilization in Peru has extensively documented and analyzed the abuse from a victim-centric, post-colonial, and intersectional perspective, there are no studies that ground coercive sterilization within the context of genocide. Studies that do discuss the violation in relation to human rights argue this to be a case of crime against humanity and not genocide. ${ }^{28}$ In fact, even the most recent formal complaint from Instituto de Defensa Legal and Estudio para la Defensa de la Mujer (DEMUS) on behalf of victims of forced sterilization against the Peruvian state has been filed under "grave human rights crimes," and violation of the "right to life," 29 but not genocide. This article aims to complement the literature by introducing a new scholarship of genocide linked to the coercive sterilization of Indigenous women in the Peruvian context. In doing so, it also contributes to existing scholarship on forced sterilization of Indigenous women and genocide in North America (i.e., Canada and the United States). It is important to state the obvious connections that exist between the sterilization of Indigenous peoples and genocide in Peru, using international instruments of human rights, namely the 1948 United Nations Genocide Convention. The categorization of the crime and rights violations defined under a genocide lens bring to light the gravity of the crime committed against the Indigenous peoples in Peru and the continued impunity for this case reveals the prevalence of domestic historical roots of racism, sexism, and class-related discrimination that overshadow the genocide.

\section{The Policy}

Programa de Salud Reproductiva y Planificación Familiar (Program of Reproductive Health and Family Planning (PSRPF)) was a national health program launched in 1996 by Alberto Fujimori's administration (1990-2000). It aimed to provide services to "promote, prevent, cure, and rehabilitate reproductive health to the highest quality" for all "inhabitants in Peru," provided that they expressed "free and voluntary consent." ${ }^{30}$ Notable program objectives included the reduction of maternal and infant mortality rates, in addition to increased national usage of contraceptive methods to reach the global average fertility rate of 2.5 children per woman. ${ }^{31}$

The increased access to contraceptive methods and education on family planning were revolutionary policies in a state, such as Peru, with conservative Catholic traditions. Even prior to the PSRPF, the Church expressed opposition to state-led family planning policies, noting that while "responsible parenting" was important, the only acceptable form of contraception was "abstinence." ${ }^{32}$ Countering such views from the Church, as Fujimori's speech during the 1995 Beijing Conference on Women reflected, PSRPF was posited to address the scarcity in maternity related services and information for women to "have at their disposal with full autonomy and freedom,

Carmela Chávez (Superintendencia Nacional de Educación Superior Universitaria (SUNEDU)), interview by author, Lima, May 26, 2017.

${ }^{27}$ Ainhoa Molina Serra, “Esterilizaciones (forzadas) en Perú: Poder y Configuraciones Narrativas," Revista de Antropología Iberoamericana 12, no. 1 (2017), 33-34.

${ }^{28}$ The following pages from Labrín are dedicated to the discussion of framing the crime as a form of crimes against humanity and not as a genocide; see Labrín, Justicia de Genero, 14-22.

${ }^{29}$ Ministerio Público, “Resolución Formalización Denuncia Caso EEFF Versión Comprimida," Ministerio Público Fiscalía de la Nación, October 31, 2018, accessed December 1, 2018, http://www.demus.org.pe/wpcontent/uploads/2019/01/12-1118-Resoluci\%C2\%A6n-Formalizaci\%C2\%A6n-denuncia-caso-EEFFversi\%C2\%A6n-comprimida.pdf, 1.

${ }^{30}$ Ministerio de Salud, Programa de Salud Reproductiva y Planificación Familiar 1996-2000 (Lima: Ministerio de Salud, 1996), 3.

${ }^{31}$ Ibid., 26.

32 "Por Programa de Planificación Familiar Enfrentamiento Fujimori-Iglesia," El Tiempo, November 2, 1990, accessed November 1, 2018, https://www.eltiempo.com/archivo/documento/MAM-2438. 
the tools necessary to make decisions about their lives." ${ }^{33}$ And yet, these progressive premises were quickly undermined during the implementation of the program. Fujimori's administration manipulated the rhetoric on advancing women's rights, connected it with the fight against poverty and controlled family planning, and justified the policy of forced sterilization. ${ }^{34}$

According to the Defensoría del Pueblo (Human Rights Ombudsman's Office), through the PSRPF, health officials performed 272,028 sterilizations on a majority of poor, rural, Indigenous Quechua-speaking women. ${ }^{35}$ With the PSRPF, health officials were required to meet obligatory sterilization quotas. The pressure exerted on health officials to meet their obligations, even involved monetary incentives when quotas were met. ${ }^{36} \mathrm{And}$, when quotas were not met, health officials faced threats of sanctions and the denial of promotions. On certain occasions, in efforts to fill these quotas women who worked in health clinics were also sterilized. ${ }^{37}$ In this context of pressure and coercion, thousands of individuals were coerced into these practices without consent and at times with false information. Women were misinformed that they would be able to give birth again after surgery, told that they were undergoing surgery to remove a tumor and not tubal ligation, or at times simply forced on a boat, taken to a health post, given anesthesia, and pushed out of the recovery room immediately after surgery. ${ }^{38}$

At times, there was no information provided. The experiences of forced sterilization were marked with difficulties of communication between the victim, who spoke an Indigenous language, and health officials, who were Spanish speaking. The majority of the victims were "illiterate and only spoke Quechua," ${ }^{\prime 39}$ which made accessing any legal means to pursue criminal accountabilitybased in the Spanish system-difficult. This linguistic barrier also became the fallback used by health officials accused of forced sterilization, as they would argue that the victim ought to have asked for a translator (who spoke an indigenous language) if they were misinformed. ${ }^{40}$ Only in 2016, with the help from human rights organizations such as the Instituto de Defensa Legal and Estudio para la Defensa de la Mujer (DEMUS), 2,074 cases of forced sterilization predominantly of Indigenous women were brought forward to the Public Prosecutor's Office. ${ }^{41}$ Although the cases were quickly shelved aside from the Public Prosecutor's Office for insufficient information, continued pressures from the IACHR, DEMUS, and other advocacy groups helped reopen the cases of forced sterilization victims. District Six Attorney Luis Landa ordered criminal investigations to be reopened against former President Alberto Fujimori on April 25, 2018, and formal criminal complaints have been made from the Public Prosecutor's Office against Fujimori, his former Health Ministers Eduardo Yong Motta, Ricardo Luis Costa Bauer, and Alejandro Aguinaga, and other related government personnel for the forced sterilization of women. ${ }^{42}$

\section{The Genocide}

This is one of the many personal testimonies of the victims of coerced sterilization in Peru-Dionicia Calderón recalls the day in 1996 when she was forcibly sterilized:

${ }^{33}$ Alberto Fujimori, “Before The IV World Conference On Women, September 15, 1995, Beijing, China," (speech, Beijing, September 15, 1995), Beijing Conference on Women, United Nations-unoffical translation from Spanish, accessed May 1, 2019, https://www.un.org/esa/gopher-data/conf/fwcw/conf/gov/950915131946.txt.

${ }^{34}$ Ewig, La Economía Política, 57.

${ }^{35}$ Defensoría del Pueblo, Decimonoveno Informe, 51. Additionally, 22,004 men were also sterilized via the PSRPF.

${ }^{36}$ Comité de América Latina y El Caribe Para la Defensa de los Derechos de la Mujer (CLADEM), Nada Personal: Reporte de Derechos Humanos Sobre la Aplicación de la Anticoncepción Quirúrgica en el Perú 1996-1998 (Lima: CLADEM, 1999$), 41$.

37 “Las Esterilizaciones Forzadas-un Crimen Que Nadie Quiere Reconocer,” Diakonia, accessed June 20, 2019, https:// www.diakonia.se/es/donde-trabajamos/peru/demus/.

${ }^{38}$ Anonymous interviewee, Quipu Project-All the Testimonies, Interactive Quipu Project, Lima, 2017, accessed July 1, 2019, https://interactive.quipu-project.com/\#/es/quipu/listen/83?currentTime=46.01\&view=thread.

${ }^{39}$ Quipu Project, “The Quipu Project,” Quipu Project, Lima, 2017, accessed July 1, 2019, https://interactive.quipu-project. com/\#/en/quipu/intro.

${ }^{40}$ Organización Nacional de Mujeres Indígenas Andinas y Amazónicas del Perú (ONAMIAP), “Testimony from Dionicia Calderón Arellano (Campesina)," ONAMIAP Public Forum and Hearing on Forced Sterilizations-Lima, 1st session, 2017.

${ }^{41}$ La República, Denuncia de Esterilizaciones Forzadas.

${ }_{42}$ "Fiscal Formaliza una Denuncia Penal Contra Fujimori por Esterilizaciones Forzadas," Agencia EFE, November 12, 2018, accessed June 2, 2019, https://www.efe.com/efe/america/politica/fiscal-formaliza-una-denuncia-penal-contra-fujimoripor-esterilizaciones-forzadas/20000035-3810933. 
They took me to the hospital in Cangallo (in the region of Ayacucho) and forced me to undergo surgery... and, when we (Dionicia along with other women) went back to the health post to complain (about the pain after surgery), the nurses would say that we were hypocrites and that it didn't hurt at all, and saying those things they threw us out. So, we never went back to the health post...we have suffered physical pain and infections, and some of us even rupture in our marriages and families. ${ }^{43}$

Peru's legal system is based on a monistic system of law, where international and internal legal systems form a unity. Under Article 55 of Peru's 1993 Constitution, international law in Peru immediately takes effect once the state becomes party to international commitments. ${ }^{44}$ All norms enshrined in treaties ratified by the state thus form a part of national law. Peru ratified the Convention on the Prevention and Punishment of the Crime of Genocide on February 24, 1960, without any reservations or declarations. Article II of the Convention defines genocide as "acts committed with intent to destroy, in whole or in part, a national, ethnical, racial or religious group." 45 Such ideas were also present under Article 319 of Peru's Penal Code that defines genocide as an act having the intention to "destroy, in whole or in part, a national, ethnic, and social or religious group." ${ }^{46}$ Both emphasize the classification of victims as a collective group and the existence of the intent to harm from the contracting parties. By 1996, when the PSRPF was implemented, the norms enshrined in the Genocide Convention and Peru's domestic legal system were legally binding.

Under Section B and D of Article II of the Genocide Convention, genocidal acts include, "causing serious bodily or mental harm to members of the group," and the imposition of "measures intended to prevent births within the group," all with the intent to destroy an entire group of population. ${ }^{47}$ Subsection IV of Article 319 of Peru's Penal Code reiterates this point, defining genocidal acts as "methods destined to impede the births" from a group with a defined national, ethnic, and social or religious characteristic. ${ }^{48}$ The story of Dionicia, which is but one of many similar experiences reported by Indigenous women, fits well within this framing of genocide. The surgery administered by state officials was intended to prevent births, caused bodily and mental harm, and impacted a specific ethnic group, which in her case represented the Quechua-speaking Indigenous community in Ayacucho. However, claiming genocide with her single case would be tricky. Genocidal acts may be committed against a few individuals by the state, as noted in the indictment of Goran Jelisic or the "Serb Adolf" who had instigated, ordered, and committed genocide against Bosnian Muslims. ${ }^{49}$ Nevertheless, making the case for genocide of a collective group based on Dionicia's story alone could be difficult. Alternatively, arguing for genocide referring to a collection of cases that manifest a pattern of conduct with documents pointing to a government's intentional targeting of women of indigenous background does expose the PSRPF as a policy of genocide. And, grounding the genocidal intent of the state on the mens rea (the guilty mind), and actus reus (the material facts), allows the policy to be understood within the larger context of genocide. The Peruvian state had both elements, the plan to forcibly sterilize a part of a population and the implementation of the conduct which resulted in the destruction of a large number of individuals of an ethnic minority. ${ }^{50}$

As previously noted, the state policy was intended to cause bodily harm. Dionicia testified about the pain she suffered after the surgery which was left untreated. Luisa Pinedo Rango, an Indigenous woman of Shipibo descent from Ucayali (in the Amazonian region of Peru), told a

${ }^{43}$ ONAMIAP Public Forum, Testimony from Arellano.

${ }^{44}$ Título II Del Estado y la Nación (Title II of the State and Nation) (1993), (Republic of Peru), accessed August 1, 2019, http://www4.congreso.gob.pe/comisiones/1996/constitucion/cons t2.htm.

${ }^{45}$ United Nations, General Assembly Resolution 260, Convention on the Prevention and Punishment of the Crime of Genocide (UN Genocide Convention), December 9, 1948 (UN Doc. A/RES/260(III)).

${ }^{46}$ Decreto Legislativo No. 635 Código Penal (2016), Ministerio de Justicia y Derechos Humanos, (Republic of Peru), http:// spij.minjus.gob.pe/content/publicaciones oficiales/img/CODIGOPENAL.pdf.

${ }^{47}$ UN Genocide Convention, Art. 2.

${ }^{48}$ Decreto Legislativo No. 635 Código Penal, 206.

${ }^{49}$ Prosecutor v. Goran Jelisic, International Criminal Tribunal for the former Yugoslavia (ICTY), IT-95-10-A, para. 17, accessed February 1, 2020, https://www.icty.org/x/cases/jelisic/ind/en/jel-ii950721e.pdf.

${ }^{50}$ William A. Schabas, Genocide in International Law: The Crime of Crimes (Cambridge: Cambridge University Press, 2009), $172-175$ 
similar story of forced sterilization. Health officials came to her native Amazonian community, urged her and other women to undergo surgery, put her on a boat, and took her and other Indigenous women to the health center. After giving her anesthesia without any information as to what was going on, she recalls, "I woke up and they told me that I could go back home... but I felt pain and I did not know what to do... they did not even give me a pill." ${ }^{51}$ The Quipu Project that audio-recorded testimonies of 135 victims and victims' families of forced sterilization documents similar experiences of twenty-nine women from Ucayali. Many were not provided with post-surgery medication. Some continue to have "abdominal pain and stomach swelling," others stated that they cannot "work as much as they did before," and that even daily chores such as cooking have become difficult. Often, victims asked in their testimony why the health officials insisted on the surgery, tricked them, and abandoned them. ${ }^{52}$ Luisa and other women's stories from the Quipu Project are corroborated by Peru's Truth and Reconciliation Commission President Salomón Lerner who observed numerous cases where after coerced tubal ligation there was no postoperative follow-up which increased the possibilities of infections and life-threatening conditions. ${ }^{53}$

The case of María Mamérita Mestanza Chávez v. Peru mediated by the IACHR also tells a similar story of intentional cruelty. In 1998, María and her husband Jacinto Salazar Suárez were threatened by health officials who claimed that they had broken the law by having more than five children. ${ }^{54}$ This false information led the couple to decide on the tubal ligation procedure on March 27, 1998. Post-surgery complications led María and her husband to seek help from medical personnel, who dismissed the symptoms as side effects of anesthesia. The denial of medical attention led to María's death on April 5, 1998. Such was also the experience of survivors, including Dionicia, Luisa, and the 135 from the Quipu Project, that make up the collective narrative from the victims. The refusal of medical personnel to respond to victims' health conditions reflected a purposeful infliction of bodily harm from the state-a sign of possible implementation of genocide.

Conforming to the categorization of genocide under Section D Article II of the Convention, there was a target group by the state that endured the prevention of births from the state. Although original program objectives were to "provide surgical intervention to men and women" 55 and vasectomies were more economical and posed a lower health risk, in the process of implementation, government documents outline the wording of genocidal intent that pushed for women to be the subjects of tubal ligation. ${ }^{56}$ Ministerial Resolution No. 089-98-SA/DM from March 10, 1998 redacts the program's reserved plans, which included the distribution of family planning methods to no less than fifty percent of the women in fertile age and their partners. ${ }^{57}$ The specific reference to "fertile" women as the recipients of the family planning policy, coincided with the PSRPF's push for tubal ligation in comparison to vasectomy. Women were the preferred group by the state that aimed to sterilize this population and prevent future births. This aspect resonates with having the planned intent (mens rea) to get rid of a population and the categorization of genocide under the Genocide Convention.

The data from the Registry of Victims of Forced Sterilization (REVIESFO) further supports the argument of the state's selective focus on women and the outcome (actus reus) backed with the number of victims. REVIESFO was established by the state via the Supreme Decree No. 006-2015, to record the number of victims of forced sterilization from 1995 to 2001. From REVIESFO data, women constituted the majority of the victims of forced sterilization. During the first year of its

\footnotetext{
${ }^{51}$ Organización Nacional de Mujeres Indígenas Andinas y Amazónicas del Perú (ONAMIAP), “Testimony from Luisa Pinedo Rango (Campesina)," ONAMIAP Public Forum and Hearing on Forced Sterilizations-Lima, 1st session, 2017.

${ }^{52}$ Anonymous interviewee, Quipu Project, Testimony 1-7.

${ }^{53}$ Salomón Lerner Fébres (President of the Truth and Reconciliation Commission of Peru), interview by author, Lima, May 31, 2017.

${ }^{54}$ IACHR, Report No. 71/03. Petition 12.191.

${ }^{55}$ del Aguila, Invisible Women, 114.

${ }^{56}$ Defensoría del Pueblo, La Aplicación de la Anticoncepción Quirúrgica y los Derechos Reproductivos III: Casos Investigados por la Defensoría del Pueblo (Lima: Defensoría del Pueblo, 2002).

${ }^{57}$ Defensoría del Pueblo, La Aplicación de la Anticoncepción Quirúrgica y los Derechos Reproductivos II: Casos investigados por La Defensoría del Pueblo (Lima: Defensoría del Pueblo, 2000), 79.
} 
implementation in 2016, REVIESFO reported a total of 3,580 cases of forced sterilization, $97 \%$ of whom were women. In 2017, out of 2,398 registered cases, $96.9 \%$ were women. In $2018,97 \%$ of the 94 recorded cases were women and, as of this writing in 2019, ${ }^{58}$ all five cases of forced sterilization have been women. ${ }^{59}$ Hence in total, out of 6,077 recognized cases of forced sterilizations by the Ministry of Justice and Human Rights, an overwhelming majority of 5,893 (97.97\%) were women who were forced to undergo surgical procedure against their will or without their consent.

Although the policy was structured on women's reproductive health, not all women were victimized. Hence, this was not a case of femicide-the systematic killing of a population comprised of the female sex. Instead, a group of women based on an ethnic category were singled out and subject to the state's genocidal measures. This approach conforms to the textual definition of genocide in that the perpetrators-which was the state-planned to use policies of coercive sterilization and effectively did so on an ethnic minority population with the intent to destroy the group. The national family planning program invoking women's access to medical care was a disguised colonialist policy to prevent the births of Indigenous peoples and diminish the Indigenous population. The colonial vision of society channeled in this program worked well with the justifications used by the state on population control of the poor sectors of society - namely the Indigenous population.

This intent from the state to harm the Indigenous population was apparent from the moment the state fertility program was being promoted. The launch of the PSRPF was directed towards eight specific regions with the objective to "better the accessibility" of the local population to health care services. These were the regions of Arequipa, Cusco, Puno, San Martín, Tacna, Junín, Ancash, and Piura. ${ }^{60}$ All eight were considered non-metropolitan rural areas, and with the exception of Tacna, San Martín, and Piura, were majority-Quechua speaking regions. Additionally, as noted by court documents filed from victims of forced sterilization against the state, irregularities against the reproductive rights of women were manifested in the Amazonas, Ancash, Apurimac, Arequipa, Ayacucho, Cajamarca, Cusco, Huancavelica, Huánuco, Junín, La Libertad, Lambayeque, Lima, Piura, Tarapoto, and Tumbes. Majority Quechua-speaking populations resided in Ancash, Apurimac, Ayacucho, Cusco, Huancavelica, Huánuco, and Junín, and areas with Jíbaro-speaking populations (an Indigenous language) included the Amazonas. ${ }^{61}$

The emphasis on Indigenous peoples was also evident from the early moments of family planning campaign promotion. Starting from 1996, Ministry of Health officials launched Health and Fertility Festivals in rural and poor communities. ${ }^{62}$ According to government census data, the majority of individuals who identify their mother-tongue as Quechua, Aymara, or Amazonian Indigenous languages reside in rural areas. These areas include the Amazonian and Andean regions, and this group constitutes 38.8 percent of Peru's total population. ${ }^{63}$ The Truth and Reconciliation Commission's President Salomón Lerner recalls seeing these festivals during one of his family trips to a rural Andean region. ${ }^{64}$ The Festival banners included messages of "Festival de ligadura de trompas, vasectomía gratis" (free tubal ligation and vasectomy festival), "Campaña gratuita de ligadura de trompas y vasectomía" (free campaign of tubal ligation and vasectomy), "Por eso elegimos el método de ligadura de trompas y vivimos felices" (That is why we chose the method of tubal ligation and we live happy), or "Campaña de vasectomía y ligadura de trompas para vivir felices" (vasectomy and tubal ligation campaign to live happy). ${ }^{65}$ The messaging aimed to frame sterilization surgeries as the optimal choice, associating the practice with happiness, "correct choice," or even monetary gains. And, given the festival locations primarily in rural areas with majority Indigenous populations, it was directed towards women from Indigenous, poor, and rural backgrounds.

\footnotetext{
${ }^{60}$ Ministerio Público, Resolución Formalización, 24.

${ }^{61}$ Instituto Nacional de Desarrollo de Pueblos Andinos, Amazónicos y Afroperuanos (INDEPA), “Mapa Etnolingüístico del Perú," Revista Peruana de Medicina Experimental y Salud Pública 27, no. 2 (2010), 288-291. 
The argument for targeting Indigenous peoples from the PSRPF was to control those who were seen by the state as the "cause of poverty," as the group that was "preventing Peru from modernization." 66 This was an old-Malthusian grounded assumption invoked in post-colonial state settings, where the vulnerable population, primarily women of color or of Indigenous descent were targeted for population "manipulation programs." ${ }^{67}$ As such, PSRPF was used by Fujimori's government to "combat poverty," via population reduction which they assumed would result in the increase of gross domestic product per capita. ${ }^{68}$ Economic justifications were used to "destroy, in whole or in part" a socioeconomic minority who were of one ethnic group, the Indigenous population of Peru. REVIESFO's 2016 data on the reported 3,580 cases of forced sterilization, pinpoints the selection of the Indigenous group apart from others. According to the registry, the majority of the victims of forced sterilization resided in Indigenous language speaking rural areas. These included, 2 cases from Pasco, 2 in Puno, 221 in Junín, 229 from Huancavelica, 342 in Huánuco, 342 in Ayacucho, and 1,293 from Cusco. Comparatively, regions with mixed languages (Spanish and Indigenous languages) registered 33 victims in Moquegua and 680 from San Martín. Other areas with more Spanish-speaking populations also reported forced sterilization cases: 73 in Lima, 101 in La Libertad, 109 in Cajamarca, and 181 in Piura. In total, out of 3,580 reported cases of forced sterilization during the first year of the victims' registry, 67.9 percent (2,431 cases) were from Indigenous-language speaking areas. And, 56.9 percent or over 2,040 ${ }^{69}$ individuals identified Quechua as their mother tongue. These characteristics of women of Indigenous descent were descriptive of the majority victim group who were coerced into these practices, without consent and at times with false information. The state knowingly focused on the sterilization campaign against these women, whose ethnic identity put them at a more vulnerable position, particularly in the context of a state equating the eradication of poverty with population control. Peru's case resembled the stories of other post-colonial states such as Canada that depended on the "control over aboriginal peoples' land and resources," and indigenous population growth, to fuel their capitalist system built on colonial and racial structural differences. ${ }^{70}$

The signs of genocidal intent were present from the beginning. By 1997, a year into the PSRPF, government officials were aware of the "irregularities" manifested with the family planning program. Two key pieces of government documents attest to the prior knowledge from the state and provides the basis for the argument of genocidal intent. The Human Rights Ombudsman's Office-an autonomous organization within the Peruvian government-received complaints of tubal ligation procedures starting in 1997. In response, the Ombudsman's Office published an investigation of the cases in 1998, that determined the PSRPF's application involved coercive elements of pressure, insufficient information on family planning options, and a disproportionate push for tubal ligation compared to vasectomies. ${ }^{71}$ Concluding the findings, the Ombudsman's Office issued a list of recommendations for the state under Resolution No. 01-98. These included the modification of the program objectives and substitution of tubal ligation, and vasectomy with other family planning methods. ${ }^{72}$ Initially, the Ministry of Health issued a letter SA-DM-No. 0284-98 published on March 6, 1998, noting their commitment to revise the policy and set up a commission to investigate the "irregularities" of the PSRPF. ${ }^{73}$ And yet, coerced sterilizations did not stop.

\footnotetext{
${ }^{66}$ Fébres, interview by author.

${ }^{67}$ Kuumba, Perpetuating Neo-Colonialism, 80.

${ }^{68}$ Ewig, La Economía Política, 57.

${ }^{69}$ During the first year when the victims' registry was implemented, REVIESFO gathered data on the mother tongue of victims of forced sterilization. Those who spoke indigenous languages included: 13-speaking Achuar, 7-Aimara, 6-Ashaninka, 1-Cauqui, 1-Matsigenka, 1-Nomatsigenga, 1-Shipibo-Konibo, and 2,010-Quechua speakers. 1,540 victims identified Spanish as their mother tongue; see Ministerio de la Mujer y Poblaciones Vulnerables, Resumen Estadístico Victimas de Esterilizaciones Forzadas 2016 (Lima: Ministerio de la Mujer y Poblaciones Vulnerables, 2016).

${ }^{70}$ Stote, The Coercive Sterilization, 117.

${ }^{71}$ Defensoría del Pueblo, Anticoncepción Quirúrgica Voluntaria I, 3.

${ }^{72}$ Ibid., 5.

${ }^{73}$ Congreso de la República, Subcomisión Investigadora: Informe 01/30/2003, Subcommittee Report from Congress, January 30, 2003, accessed May 1, 2019, http://www2.congreso.gob.pe/sicr/apoycomisiones/informes.nsf/
} 
According to documents from the Congressional Investigative Commission on Crimes related to Voluntary Tubal Ligation Procedures from 1996-2000, the director of the Basic Health Care Unit of Chumbivilcas in the region of Cusco admitted to holding a round of tubal ligations in $1999 .{ }^{74}$ The surgeries in Chumbivilcas were notorious for being staffed with unqualified surgeons and for not having an anesthesiologist present in the tubal ligation procedures. ${ }^{75}$ One of the women, Santusa Taype Chlla, who was sterilized in the Santo Tomas Health Center in Chumbivilca on July 10, 1999, died of post-surgery health complications on July 12, 1999. Hence, parallel to the expression of concern issued by the Ministry of Health, the state also continued pushing for coercive sterilizations. Investigations of irregularities in the family planning policies never materialized. Instead, health posts that met sterilization quotas received useful equipment from the Ministry of Health. How was this possible? Fujimori's government had a goal to accomplish, which was "combating poverty." 76 To do so, the central government set up a family planning policy aimed at preventing the population growth of those who were categorized as the source of poverty. The prejudices that sustained this policy reflected a colonialist mentality embedded in governing hierarchies that regarded the indigenous peoples as a dispensable group, whose lives could be destroyed in part or whole without any repercussions of criminal accountability or justice.

Along with the Ombudsman's Office investigation, forced sterilization was brought up during the fourth meeting of the Second Regular Session of the Legislature on March 18, 1998. As redacted in congressional session notes, Congressman Roger Guerra-García informed the legislature about the government's population policy, referring to the PSRPF. He explained that a population policy need not be limited to the "control of population growth or the phenomenon of sterilization."77 This was an indirect criticism at the restricted insights of the government policy that promulgated sterilization as the single best option. Then, Guerra-García noted the existence of complaints against those who "implement" the government policy, referring to the healthcare professionals, and explained the malpractice of coerced sterilizations that have "put at risk the life and health" of many. ${ }^{78}$ These were comments directed against the human rights violations caused by the state. Both the investigative report from the Human Rights Ombudsman's Office and the congressional speech were delivered in 1997 and 1998. Hence, the state was aware of forced sterilizations and its associated human rights violations from the early phase of PSRPF's implementation. And yet, the government did not revise the policy and stop the bodily harm. Daily newspapers El Comercio, Diario El Sol, and La República reported on "tricked" and "forced sterilizations" in the province of Cusco that took place in $1999 .{ }^{79}$ The refusal to revisit the malpractice of sterilization was a consistent signal of genocidal intent from the state, one that prioritized the prevention of births of a population, the majority of whom were women of Indigenous descent.

There are questions as to the intentionality of the PSRPF in destroying "in whole or in part" a particular population. Nongovernmental organizations defending the victims of forced sterilization are hesitant to admit a genocide, noting that there is not enough evidence to categorize the state's intentions as having the goals of annihilating a group of peoples who were impoverished, resided in rural areas, worked the fields, and were of Indigenous or Andean descent. The intentions had more to do with birth control in certain populations. ${ }^{80}$ It is important to note that reference to "birth control" is not equivalent to the "prevention of births" that is explained in the Genocide Convention. The sterilization practice against women predominantly of Indigenous background

InformesPorComision/C405450DEB310E6C0 5256CBE0076A35E.

\footnotetext{
${ }^{74}$ Ibid.

${ }^{75}$ Ministerio Público, Resolución Formalización, 24.

${ }^{76}$ Boesten, Free Choice, 15. nt.

${ }^{78}$ Ibid.

${ }^{79}$ Ministerio Público, Resolución Formalización, 30.

${ }^{80}$ Labrín, Justicia de Genero, 16-18.
}

${ }^{77}$ Congreso de la República, Diario de los debates: Segunda Legislatura Ordinaria de 1997 4ª Sesión Miércoles 18 de marzo de 1998, Congreso de la República, March 18, 1998, accessed May 1, 2019, http://www2.congreso.gob.pe/sicr/ diariodebates/Publicad.nsf/2b66b8a68552546d05256f1000575a5c/05256d6e 0073dfe9052565d1007dcde5?.OpenDocume 
was not to inform the population of birth control or family planning practices. These experiences were designed to forcibly prevent the births of more children, as had been the case with the indigenous population in Canada.$^{81}$ The surgical acts in Peru were performed against the women's will, where at times women would be locked up and, in other instances, forced to take anesthesia. ${ }^{82}$ There could not be a clearer evidence of state intent to make the case for genocide.

\section{What Remains}

Over the course of five years from 1996 to 2001, the Peruvian state implemented a family planning program with alleged progressive objectives that focused on educating the public of contraceptive methods, reducing infant and maternal mortality rates, and protecting women's reproductive rights. However, with the implementation of the program, the objectives changed towards an aggressive campaign of forced sterilization that used coercion and manipulation to target a vulnerable population of society. Indigenous women from poor economic backgrounds constituted most of the victims.

Despite the evidence that points to the genocidal intent of the state and the physical evidence of bodily harm caused by the PSRPF, this is a case that has yet to be considered as a crime against humanity, let alone as a genocide. What remains from the family planning policy are the violations endured by the victims and their family members, many of whom remain waiting for justice and reparations. Even the family members of María Mamérita Mestanza Chávez have yet to receive all the different measures of reparations. This is in spite of María Mamérita Mestanza Chávez's death and the subsequent petition from nongovernmental organizations to the IACHR that led to a friendly agreement in 2003 between the state and the victim's family. Mamérita's daughters and sons have not received financial assistance for education. And, other 1,316 women included in the legal complaint filed against Fujimori and his cabinet officials ${ }^{83}$ have not received any form of criminal accountability or reparations as of the time of this writing.

The other factor that remains unspoken within this unacknowledged context of genocide is the identification of the majority of victims - the Indigenous populations of Peru. The targeting of these ethnic groups has gone unnoticed and pushed aside. As conquistadors and colonizers of Peru, the Spanish ruled with the idea of ethnic superiority. Such is symptomatic of the perspective of ethnicity and socioeconomic class from the colonial period of Peru, one which has continued to shape society's deprecation towards Indigenous peoples and cultures today ${ }^{84}$ From this viewpoint, the elimination in "whole or in part" of the Indigenous populations was not a problematic outcome, as it would help the state establish population control and improve national economic standards. That had been the goal of Fujimori's government. In this context, the Indigenous peoples became a population that need not be replaced, one that could be subject to genocide via coercive sterilization practices and the prevention of births of future generations of Indigenous children. Such was the intended outcome, the policy structured around this plan, and the resulting genocide of indigenous peoples.

\section{Bibliography}

Agencia EFE. "Fiscal Formaliza una Denuncia Penal Contra Fujimori por Esterilizaciones Forzadas." November 12, 2018. Accessed June 2, 2019. https://www.efe.com/efe/america/ politica/fiscal-formaliza-una-denuncia-penal-contra-fujimori-por-esterilizacionesforzadas/20000035-3810933.

Ballón Gutiérrez, Alejandra. “El Caso Peruano de Esterilización Forzada: Notas Para una Cartografía de Resistencia." Aletheia 5, no. 9 (2014), 1-19.

Boesten, Jelke. "Free Choice or Poverty Alleviation? Population Politics in Peru under Alberto Fujimori." European Review of Latin American and Caribbean Studies 82, (2007), 3-20. Doi: $10.18352 /$ erlacs. 9637

\footnotetext{
${ }^{81}$ Stote, The Coercive Sterilization.

${ }^{82}$ ONAMIAP Public Forum, Testimonies from Arellano and Rango.

${ }^{83}$ Ministerio Público, Resolución Formalización.

${ }^{84}$ Carranza Ko, Forcibly Sterilized, 161.
} 
Carranza Ko, Nusta. "Forcibly Sterilized: Peru's Indigenous Women and the Battle for Rights." In Human Rights as Battlefields: Changing Practices and Contestations, edited by Gabriel Blouin-Genest, Marie-Christine Doran, and Sylvie Paquerot, 149-172. New York: Palgrave Macmillan, 2019. Doi: 10.1007/978-3-319-91770-2 8

Comité de América Latina y El Caribe Para la Defensa de los Derechos de la Mujer (CLADEM). Nada Personal: Reporte de Derechos Humanos Sobre la Aplicación de la Anticoncepción Quirúrgica en el Perú 1996-1998. Lima: CLADEM, 1999.

Comisión de la Verdad y Reconciliación. Final Report. Lima: Comisión de la Verdad y Reconciliación, 2003. Accessed August 1, 2019. http://www.cverdad.org.pe/ingles/ifinal/index.php.

Congreso de la República. Diario de los debates: Segunda Legislatura Ordinaria de $19974^{a}$ Sesión Miércoles 18 de marzo de 1998. Congreso de la República. March 18, 1998. Accessed May 1, 2019. http://www2.congreso.gob.pe/sicr/ diariodebates/Publicad.nsf/2b66b8a68552546d05256f1000575a5c/05256d6e 0073dfe9052565d1007dcde5?OpenDocument.

---------. Subcomisión Investigadora: Informe 01/30/2003. Subcommittee Report from Congress. January 30, 2003. Accessed May 1, 2019. http://www2.congreso.gob.pe/sicr/apoycomisiones/ informes.nsf/InformesPorComision/C405450DEB310E6C0 5256CBE0076A35E.

Constitución Política de la República Peruana Sancionada por el Primer Congreso Constituyente (Political Constitution of the Republic of Peru Approved by the First Constituent Congress). November 12, 1823. (Republic of Peru). Accessed August 1, 2019. http://www. leyes.congreso.gob.pe/Documentos/constituciones ordenado/CONSTIT 1823/Cons1823 TEXTO. pdf.

De La Cruz Huamán, Rosario B. "Análisis de las Esterilizaciones Forzadas en el Perú desde una Perspectiva de Interculturalidad Critica." Tierra Nuestra 12, no. 1 (2018), 105-117. Doi: $10.21704 /$ rtn.v12i1.1272

Decreto Legislativo No. 635 Código Penal (2016). Ministerio de Justicia y Derechos Humanos (Republic of Peru). http://spij.minjus.gob.pe/content/publicaciones_oficiales/img/ CODIGOPENAL.pdf.

Defensoría del Pueblo. Decimonoveno Informe Anual de la Defensoría del Pueblo. Lima: Defensoría del Pueblo, 2015.

--------. Anticoncepción Quirúrgica Voluntaria I: Casos Investigados por la Defensoría del Pueblo. Lima: Defensoría del Pueblo, 1998.

--------. La Aplicación de la Anticoncepción Quirúrgica y los Derechos Reproductivos II: Casos investigados por La Defensoría del Pueblo. Lima: Defensoría del Pueblo, 2000.

--------. La Aplicación de la Anticoncepción Quirúrgica y los Derechos Reproductivos III: Casos Investigados por la Defensoría del Pueblo. Lima: Defensoría del Pueblo, 2002.

del Aguila, Ernesto Vasquez. "Invisible Women: Forced Sterilization, Reproductive Rights, and Structural Inequalities in Peru of Fujimori and Toledo." Estudos e Pesquisas em Psicología UERJ RJ 6, no. 1 (2006), 109-124.

Diakonia. "Las Esterilizaciones Forzadas-un Crimen Que Nadie Quiere Reconocer.” Accessed June 20, 2019. https://www.diakonia.se/es/donde-trabajamos/peru/demus/.

El Tiempo. "Por Programa de Planificación Familiar Enfrentamiento Fujimori-Iglesia." El Tiempo, November 2, 1990. Accessed November 1, 2018. https://www.eltiempo.com/archivo/ documento/MAM-2438.

Ewig, Christina. "La Economía Política de Esterilización Forzada en el Perú." In Memorias del caso peruano de esterilización forzada, edited by Alejandra Ballón, 47-72. Lima: Biblioteca Nacional del Perú, 2014.

Fujimori, Alberto. “Before The IV World Conference On Women, September 15, 1995, Beijing, China." Speech, Beijing, September 15, 1995. Beijing Conference on Women, United Nations - unoffical translation from Spanish. Accessed May 1, 2019. https://www.un.org/ esa/gopher-data/conf/fwcw/conf/gov/950915131946.txt.

Getgen, Jocelyn E. "Untold Truths: The Exclusion of Enforced Sterilizations from the Peruvian Truth Commission's Final Report." Boston College Third World Law Journal 29, no. 1 (2009), 1-34. Doi: $\underline{10.2139 / \text { ssrn. } 1271449}$ 
Instituto Nacional de Desarrollo de Pueblos Andinos, Amazónicos y Afroperuano (INDEPA). "Mapa Etnolingüístico del Perú." Revista Peruana de Medicina Experimental y Salud Pública 27, no. 2 (2010), 288-291. Doi: 10.1590/S1726-46342010000200019

Instituto Nacional de Estadística e Informática (INEI). Dinámicas Étnicas en el Perú. Lima: INEI, 2017.

Inter-American Commission on Human Rights (IACHR). Report No. 71/03. Petition 12.191. Friendly Settlement María Mamérita Mestanza-Chávez. Peru: IACHR, 2003. Accessed August 1, 2019. http://cidh.org/annualrep/2003eng/Peru.12191.htm.

Kuumba, Monica Bahati. "Perpetuating Neo-Colonialism through Population Control: South Africa and the United States." Africa Today 40, no. 3 (1993), 79-85.

La República. "Denuncia de Esterilizaciones Forzadas Fue Archivada por la Fiscalía." La República, July 27, 2016. Accessed June 2, 2019. http://larepublica.pe/sociedad/789156-denuncia-deesterilizaciones-forzadas-fue-archivada-por-la-fiscalia.

Labrín, José Burneo. Justicia de Genero: Esterilización Forzada En El Perú: Delito de Lesa Humanidad. Lima: Editorial Linea Andina, 2008.

Mantilla Falcón, Julissa. “El Caso de las Esterilizaciones Forzadas en el Perú Como una Violación de los Derechos Humanos." Ius et Veritas 23, (2016), 10-20.

Ministerio de la Mujer y Poblaciones Vulnerables. Resumen Estadístico Victimas de Esterilizaciones Forzadas 2019. Lima: Ministerio de la Mujer y Poblaciones Vulnerables, 2019.

---------. Resumen Estadístico Victimas de Esterilizaciones Forzadas 2018. Lima: Ministerio de la Mujer y Poblaciones Vulnerables, 2018.

---------. Resumen Estadístico Victimas de Esterilizaciones Forzadas 2017. Lima: Ministerio de la Mujer y Poblaciones Vulnerables, 2017.

---------. Resumen Estadístico Victimas de Esterilizaciones Forzadas 2016. Lima: Ministerio de la Mujer y Poblaciones Vulnerables, 2016.

Ministerio de Salud. Programa de Salud Reproductiva y Planificación Familiar 1996-2000. Lima: Ministerio de Salud, 1996.

Ministerio Público. "Resolución Formalización Denuncia Caso EEFF Versión Comprimida." Ministerio Público-Fiscalía de la Nación, October 31, 2018. Accessed December 1, 2018. http://www.demus.org.pe/wp-content/uploads/2019/01/12-11-18-Resoluci\%C2\%A6nFormalizaci\%C2\%A6n-denuncia-caso-EEFF-versi\%C2\%A6n-comprimida.pdf.

Organización Nacional de Mujeres Indígenas Andinas y Amazónicas del Perú (ONAMIAP). Public Forum and Hearing on Forced Sterilizations-Lima. 1st session, 2017.

Puño, Julio Davila. Perú: Gobiernos Locales y Pueblos Indígenas. Lima: Tarea Grafica Educativa, 2005.

Quipu Project. "Quipu Project." 2017. Accessed July 1, 2019. https://interactive.quipu-project. com/\#/en/quipu/intro.

--------. “Testimony 1-10" Quipu Project, 2017. Accessed July 1, 2019. https://interactive.quipuproject.com/\#/es/quipu/listen/intronode?currentTime=0\&view=thread.

Schabas, William A. Genocide in International Law: The Crime of Crimes. Cambridge: Cambridge University Press, 2009. Doi: 10.1017/CBO9780511575556

Serra, Ainhoa Molina. "Esterilizaciones (forzadas) en Perú: Poder y configuraciones narrativas." Revista de Antropología Iberoamericana 12, no. 1 (2017), 31-52. Doi: 10.11156/aibr.120103

Smith, Andrea. Conquest-Sexual Violence and American Indian Genocide. Durham: Duke University Press, 2005.

Stote, Karen. "The Coercive Sterilization of Aboriginal Women in Canada." American Indian Culture and Research Journal 36, no. 3 (2012), 117-150. Doi: 10.17953/aicr.36.3.7280728r6479j650

Título II Del Estado y la Nación (Title II of the State and Nation), 1993 (Republic of Peru). Accessed August 1, 2019. http://www4.congreso.gob.pe/comisiones/1996/constitucion/cons t2.htm.

United Nations. General Assembly Resolution 260, Convention on the Prevention and Punishment of the Crime of Genocide. December 9, 1948. UN Doc. A/RES/260(III).

Wesley-Esquimaux, Cynthia C., and Magdalena Smolewski. Historic Trauma and Aboriginal Healing. Ottawa: Aboriginal Healing Foundation, 2004. 